\title{
HEALTH CARE TECHNOLOGY STANDARDS
}

\author{
J.M. ShaPLey, M.D.
}

Fon A NUMBER OF YEARS now it has been the writer's privilege and pleasure to participate in the Committee work of the Canadian Standards Association as it pertains to health matters. Since the publication of Z.32 "Code for Use of Flammable Anaesthetics" in 1963, the work has expanded to take in a great many of the aspects of health care. In a recent re-organization of the Committee structure the original Z.32 Committee has been combined with the Committee on Anaesthetic Equipment (Z.168) and others to form the "Sectional Committee on Health Care Technology." During the past two decades many members of the Canadian Anaesthetists' Society have been involved in the work of these Standards Committees, and through them in the development of International Standards by the International Standards Organization.

At the last meeting of the Committee on Health Care Technology the Sudbury tragedy was brought to the notice of the members, and it was realized and brought to the attention of the meeting that our standards are not adequately advertised to the medical profession and to "authorities" at large. For example, the testing of gas pipe lines was specified in Z.32 in 1963 and repeated in Z.32.1 in 1970. Consulting engineers asked to investigate the Sudbury incident approached the National Fire Prevention Association in Boston rather than the Canadian Standards Association. They were quickly advised that we had our own publications on this matter. As a result of this, in discussion with the Editor it was decided to publish in the Journal a list of the standards presently available, and those to be published, hopefully, in the near future. All of these standards may be purchased for prices from $\$ 2.00$ to $\$ 6.00$, from the Canadian Standards Association, 178 Rexdale Boulevard, Rexdale, Ontario M9W $1 R 3$.

The attachment is a list of the standards published to date, and others in preparation for the future. As these become available a notice will be put in the Journal. In addition to the standards it is hoped that a facility will be opened to evaluate clinical, laboratory and electro-medical equipment in 1974. Again when this has been done the readers will be notified in the Journal.

\section{C.S.A. STANDARDS PUBLISHED PRIOR TO 1973}

Safety Standards for Electrical Equipment

C.22.2 No. 121-1959, Electric Heating Equipment for Medical and Dental Use;

C.22.2 No. 114-1961, X-Ray Equipment;

${ }^{\circ} \mathrm{C} .22 .2$ No. 125-1964, High Frequency Therapeutic and Electro-Surgical Equipment. 
OTHERS

Z.39-1959, Code for Marking of Portable Compressed Gas Containers to Identify the Material Contained;

'Z.32-1963, Code for Use of Flammable Anaesthetics (Safe Practices for Hospital Operating Rooms).

Z.32.1-1970, Code for Prevention of Explosions or Electric Shock in Hospital Operating Rooms;

'Z.168.1-1963, Endotracheal Tubes;

Z.168.1-1970, Tracheal Tubes;

Z.168.2-1967, Endotracheal Tube Connectors and Adaptors;

Z.65-1966, Radiation Hazards from Electronic Equipment.

\section{C.S.A. STANDARDS PUBLISHED OR APPROVED IN 1973}

Safety Standards for Electrical Equipment

C.22.2 No. 125-1973, Electromedical Equipment, Dec. 1973.

\section{OTHERS}

Z.32.3-1973, Non-Flammable Medical Gas Piping Systems.

Z.76-1973, Performance of Child Resistant Packaging.

Z.180.1-1973, Purity of Compressed Air for Breathing Purposes.

Z.275.1, Hyperbaric Facilities (Approved).

\section{RÉSUMÉ}

Durant de nombreuses années l'auteur a eu l'honneur et le privilège de participer aux travaux de l'Association Canadienne des Standards, au niveau de son Comité des Affaires de la Santé. Depuis la publication en 1963 d'un "Code d'Instructions pour l'Emploi d'Agents Anesthésiques Inflammables", (Z-32), ce Comité a vu son champ d'action s'élargir pour englober plusieurs autres aspects de la Santé Publique. Une récente réorganisation des structures a créé un Comité de la Technologie de la Santé Publique (né de la fusion des comités Z-32, agents anesthésiques, des comités Z-168, équipement anesthésique et autres). Les 20 dernières années ont vu plusieurs membres de la Société Canadienne des Anesthésistes participer à ces travaux en comités de l'Association Canadienne des Standards; à travers celle-ci, ils ont ainsi collaboré à l'instauration de ces standards internationaux par l'entremise de l'Organisation Internationale des Standards.

Au cours de sa dernière séance, le Comité de la Technologie de la Santé Publique a été saisi de la tragédie de Sudbury et ont a réalisé à cette occasion que nos propres standards que nous avons nous-mèmes édictés, ne sont pas suffisamment connus de la profession médicale et des autorités en général. Par exemple la vérification des canalisations des gaz était bel et bien spécifiée dans la publication Z-32 en 1963 et de nouveau spécifiée dans la publication Z-32.1 en 1970. Les ingénieurs-conseils priés d'investiguer l'incident de Sudbury ont d'abord communiqué avec la National Fire Prevention Association à Boston, plutôt qu'avec l'Association Canadienne des Standards. On les a rapidement informé que nous avions nos propres publications à ce sujet. Conséquemment, après discussion avec l'éditeur de ce Journal, nous avons décidé de publier la liste des standards déjà disponibles et ceux dont on peut 
espérer la publication prochaine. On peut obtenir ces publications dont le prix s’échelonne de $\$ 2.00$ à $\$ 6.00$, de la Société Canadienne des Standards, 178 Rexdale Boulevard, Rexdale, Ontario M9W 1R3. La liste annexée contient les standards publiés à ce jour et ceux qui sont actuellement en préparation; leur parution scra signalée aux lecteurs de ce Journal. De plus, en 1974, on espère pouvoir mettre sur pied un laboratoire d'essai qui évaluera les instruments médicaux offerts aux médecins pour utilisation en clinique ou en laboratoire. Là encore une fois, ce laboratoire créé, les lecteurs de ce Journal en seront avisés. 